\title{
Platinum Group Elements in Road Dust and Vegetation from Some European and National Roads with Intensive Car Traffic in Romania
}

\author{
GABRIELA GEANINA VASILE ${ }^{1 *}$, CRISTINA DINU ${ }^{1,2 \#}$, LIDIA KIM ${ }^{1 *}$, ANDA TENEA ${ }^{1}$, MARIUS SIMION ${ }^{1}$, CORINA ENE ${ }^{3}$, \\ CLAUDIU SPINU ${ }^{1}$, ELEONORA-MIHAELA UNGUREANU' ${ }^{2}$, DANIEL MANOLACHE ${ }^{1}$ \\ ${ }^{1}$ National Research and Development Institute for Industrial Ecology - ECOIND, 71-73 Drumul Podul Dambovitei Str., 060652, \\ Bucharest, Romania \\ 2 University Politehnica of Bucharest, Faculty of Applied Chemistry and Materials Science, 1-7 Polizu Str., 011061, Bucharest, \\ Romania \\ 3Petroleum-Gas University of Ploiesti, Faculty of Economic Sciences, 39 Bucharest Blvd., 100680, Ploiesti, Romania
}

\begin{abstract}
The paper presents a monitoring study of the platinum group metals concentrations in 17 samples of road dust and vegetation from areas with heavy car traffic on several European and national roads in eastern Romania. The Ir, Pd, Pt, Rh, Ru concentrations were determined by the ICP-MS technique, the reported values being below the method's limit of determination for Ir, Pt and Ru both in soil and vegetation. As regards the Pd content, it showed a maximum of $794 \mu \mathrm{g} / \mathrm{kg}$ dry matter in Focsani area (DN2), an area where, according to national data published by National Road Infrastructure Management Company, the traffic average is 16,000 vehicles / $24 \mathrm{~h}$. Approximately $50 \%$ of the collected vegetation samples showed a $P d$ transfer factor from the solid part to the vegetation higher than 0.5, thus indicating the existence of $P d$ toxic compounds bioavailable for vegetation. The highest concentrations of $R h$ in soil were recorded on a high traffic section on the E85, in Ramnicu Sarat area, where the traffic interval ranges from 8,001 to 16,000 vehicles / $24 \mathrm{~h}$.
\end{abstract}

Keywords: PGEs, road dust, vegetation, $P d$, Rh, pollution

Over the last decade, the concentration of Platinum Group Elements (PGEs) in environmental samples such as soil, surface water, sediment and vegetation have increased significantly, the main source of contamination with these platinum metals being catalytic converters.

Increased concentrations of platinum group metals have been found in various water samples (rainwater, groundwater, surface water, marine sediments), these concentrations being caused by exhaust emissions. Large platinum concentrations have been also found near mines, especially those extracting nickel ores.

Catalysts containing platinum group metals are used especially in motor vehicles but also in industry as stationary catalysts used for the oxidation of ammonia. The main sources of platinum group metal emissions in Europe can be listed as follows: $50.4 \%$ from catalysts, $24.7 \%$ from jewelry, $6 \%$ from the electrical industry, $4.8 \%$ from the chemical industry, $4.6 \%$ from the glass industry, $2.6 \%$ from the oil industry and $6.8 \%$ from other sources [ 1 - 3].

Platinum group metals such as platinum, palladium and rhodium are used as catalysts in catalytic converters of thermal motors in order to reduce hydrocarbons, nitrogen oxides and carbon monoxide emissions. Direct measurements of PGE emissions from vehicle catalysts provide estimates of emissions expressed in $\mathrm{ng} / \mathrm{km}$ traveled. Emissions of platinum-based particles depend on factors such as engine operating conditions, age and type of catalyst, platinum metals content, vehicle speed, and type of additive present in fuel [4]. Platinum metal emissions may increase due to operating conditions, such as excessive heating, which can destroy the converter. It is assumed that the mechanical erosion of the catalyst surface is the main cause of platinum metal emissions, besides the contribution of thermal and chemical processes. The platinum metal particles resulting from the cars evacuation systems have dimensions between 1-63 ìm, being absorbed on the surface of particulate matter (PM) and depositions in air [5-6].

Platinum metal content in unpolluted soils is very low, according to data published by various groups of researchers [7-9]. Controlling these elements in environmental factors is difficult because of the performance equipment required to quantify concentrations. Published data on PGEs content in the surface layer of different soil types are discrepant and in some cases are not in accordance with natural abundance in the earth's crust [10]. The differences between the concentration range of PGEs in soil from the published data can be attributed to some aspects such as: the chemical analyzes of these metals are insufficiently elaborated; experimental data is insufficiently systematized in terms of origin (geochemical structure) and soil type, so it is difficult to estimate the representativeness of reported data.

Anthropogenic activity has led to an increase in PGE concentration in soil, especially in areas with high traffic, as evidenced by a series of studies conducted internationally [11]. The results of PGE determination in samples taken from areas located near roadways / highways indicate a decrease in the platinum metal concentration as the distance to roadways / highways increases.

Due to the fact that PGEs are mainly emitted in the metallic form, they show low toxicity. Some of them are transformed into soluble form, becoming bio-available and dangerous for both flora and fauna [1] .

Soluble platinum represents less than $10 \%$ of total Pt emissions, while soluble $P d$ and $R h$ representing more than $50 \%$. Soluble compounds of Pt as well as $\mathrm{Pd}$ and $\mathrm{Rh}$ chlorides are mutagenic, carcinogenic, and some compounds of platinum metals are strong allergens [4, 12]. Literature data show that PGEs (especially Pd) are 
absorbed from the soil through roots and subsequently incorporated into the vegetative biomass of biologically active substances [13]. The ability of plants to absorb PGE from soil can pose a significant threat to human health.

In order to monitor the emission of platinum metals into the environment, advanced analytical methods for determining these elements are required.

Methods for the determination of platinum metals include: simultaneous determination of Pt, Pd, Ir by SPEICP-OES [14]; simultaneous determination of Rh and Ru in river waters and municipal sewage through HR-CS-GFAAS [15]; simultaneous determination of Rh, Ru, Pt, Pd, Ir by ICP-OES and ICP-MS [13, 16]; determination of Pt, Pd and Rh from dust and soil samples by GFAAS [17].

Given that over the last 10 years Romania has become a country in which a large number of second-hand cars with advanced wear degree (mostly diesel) purchased from the West European countries (mainly Germany) and the UK, the purpose of this study was to estimate the impact of PGE emissions from exhaust gases on environmental factors. In this respect, the research consists in the determination of platinum metals group content (Ir, $\mathrm{Pd}, \mathrm{Pt}, \mathrm{Rh}$ and $\mathrm{Ru}$ ) in road dust and vegetation from 17 locations situated in the eastern part of Romania (European and national roads with intense car traffic) through different analytical techniques (USN-ICP-EOS and ICP-MS).

\section{Experimental part \\ Studied area}

Soil and vegetation samples have been collected according to the international standards in force at several intersections with heavy road traffic on several European roads, including the E85 road linking Turkey, Bulgaria and Ukraine to the Republic of Moldova, highly circulated, with sampling points in Buzau, Bacau, Roman, Vama Siret; European road E58 (Iasi area); European road E574 (Onesti), as well as from several national roads (eg DN2).

The geographic coordinates and description of the sampling points as well as the types of samples taken are shown in table 1.

The location of the 17 sampling points for road dust and vegetation on the road map of Romania is presented in Figure 1, whereas figures 2-5 detail several areas of interest from where samples were taken.

\section{Materials and methods}

Road dust samples were air-dried, ground, sieved, retaining the fraction with a particle size of less than $63 \mu \mathrm{m}$. Platinum metal extraction was performed with a mixture of royal water in a closed system, the samples being filtered afterwards and brought with ultra-pure water to a $50 \mathrm{~mL}$ flask. As far as the preparation of the vegetation samples is concerned, drying was done in a very good ventilation room for a period of 2 weeks. Subsequently, the vegetation samples were milled and processed (about $1 \mathrm{~g}$ ) with a mixture of hydrogen peroxide $(2 \mathrm{~mL})$ and suprapur nitric acid $(10 \mathrm{~mL})$.

The calibration curve for the determination of $\mathrm{Ir}, \mathrm{Pd}, \mathrm{Pt}$, $\mathrm{Rh}$, Ru was performed on a range from 10 to $50 \mu \mathrm{g} / \mathrm{L}$ using a MRC multi-element for ICP-MS standard 3 of $10 \mathrm{mg} / \mathrm{L}$ ( $\mathrm{Sb}, \mathrm{Au}, \mathrm{Hf}, \mathrm{Ir}, \mathrm{Pt}, \mathrm{Rh}, \mathrm{Ru}, \mathrm{Te}$ ) in $10 \% \mathrm{HCl}$ and $1 \% \mathrm{HNO}$ from VWR Chemicals.

According to the data published by the National Road Infrastructure Management Company, the Technical Studies and Informatics Center [18], E85 sections (fig. 2), from which road dust and vegetation samples were collected, shows on average a traffic higher than 16,000 vehicles / 24 hours in Buzau and between Focsani and

\begin{tabular}{|c|c|c|c|}
\hline $\begin{array}{l}\text { Crt. } \\
\text { No. }\end{array}$ & Sampling location & Sample type & GPS coordinates \\
\hline 1 & $\begin{array}{l}\text { Buzau roundabout (near Petrom gas station, Dedeman, exit to } \\
\text { Ramnicu Sarat), E85 }\end{array}$ & $\begin{array}{l}\text { S1 - road dust } \\
\text { V1 - vegetation }\end{array}$ & $\begin{array}{l}45.170867, \\
26.816423\end{array}$ \\
\hline 2 & Ramnicu Sarat roundabout (Maracineni bridge), E 85 & $\begin{array}{l}\text { S2 - road dust } \\
\text { V2 - vegetation }\end{array}$ & $\begin{array}{l}45.382008, \\
27.037951\end{array}$ \\
\hline 3 & Focsani roundabout, Vrancea county, DN2 & $\begin{array}{l}\text { S3 - road dust V3 } \\
\text { - vegetation }\end{array}$ & $\begin{array}{l}45.687543, \\
27.198295\end{array}$ \\
\hline 4 & Adjud roundabout, Republicii Boulevard & $\begin{array}{l}\mathrm{S} 4 \text { - road dust V4 } \\
\text { - vegetation }\end{array}$ & $\begin{array}{l}46.100912, \\
27.179948\end{array}$ \\
\hline 5 & $\begin{array}{l}\text { Onesti roundabout (Calea Marasesti, Redului stree, exit to } \\
\text { Adjud) }\end{array}$ & $\begin{array}{l}\text { S5 - road dust } \\
\text { V5 - vegetation }\end{array}$ & $\begin{array}{l}46.252254, \\
26.795575\end{array}$ \\
\hline 6 & Onesti roundabout (exit to $\mathrm{Tg}$. Secuiesc), E574 & $\begin{array}{l}\text { S6- road dust } \\
\text { V6 - vegetation }\end{array}$ & $\begin{array}{l}46.244557 \\
26.755675\end{array}$ \\
\hline 7 & Vulturi village roundabout, exit to Iasi E58 & $\begin{array}{l}\text { S7 - road dust } \\
\text { V7 - vegetation }\end{array}$ & $\begin{array}{l}47.239629 \\
27.532343\end{array}$ \\
\hline 8 & Vama Siret crossroad, E85 & $\begin{array}{l}\text { S8 - road dust } \\
\text { V8 - vegetation }\end{array}$ & $\begin{array}{l}47.961830 \\
26.071220\end{array}$ \\
\hline 9 & Gura Humorului roundabout, Paltinoasa village & $\begin{array}{l}\text { S9 - road dust V9 } \\
\text { - vegetation }\end{array}$ & $\begin{array}{l}47.544905, \\
25.946498\end{array}$ \\
\hline 10 & $\begin{array}{l}\text { Roman roundabout (near Petrom gas station, Nicolae } \\
\text { Balcescu street, exit to the ring road) }\end{array}$ & $\begin{array}{l}\text { S10 - road dust } \\
\text { V10 - vegetation }\end{array}$ & $\begin{array}{l}46.926710 \\
26.908728\end{array}$ \\
\hline 11 & $\begin{array}{l}\text { Roman roundabout, ring road (Roman Musat Bld, near Mol } \\
\text { gas staion), E85 }\end{array}$ & $\begin{array}{l}\text { S11 - road dust } \\
\text { V11 - vegetation }\end{array}$ & $\begin{array}{l}46.917591 \\
26.922914\end{array}$ \\
\hline 12 & Bacau roundabout (Unirii Bld., entry from Roman), E 85 & $\begin{array}{l}\text { S12 - road dust } \\
\text { V12 - vegetation }\end{array}$ & $\begin{array}{l}46.571693, \\
26.921485\end{array}$ \\
\hline 13 & Buzau roundabout, Industriilor Bld. & $\begin{array}{l}\text { S13 - road dust } 1 \\
\text { V13 - vegetation }\end{array}$ & $\begin{array}{l}45.133551 \\
26.816032\end{array}$ \\
\hline 14 & $\begin{array}{l}\text { Orbeni village crossroads, Bacau county (near Capul Dacului } \\
\text { Motel), E85 }\end{array}$ & $\begin{array}{l}\text { S14 - road dust } \\
\text { V14 - vegetation }\end{array}$ & $\begin{array}{l}46.280108, \\
27.053537\end{array}$ \\
\hline 15 & Varsatura village roundabout, Promenada Mall, Braila county & $\begin{array}{l}\text { S15 - road dust } \\
\text { V15 - vegetation }\end{array}$ & $\begin{array}{l}45.207500 \\
27.915151\end{array}$ \\
\hline 16 & Lacul Sarat roundabout, Chiscani, Braila & $\begin{array}{l}\text { S16 - road dust } \\
\text { V16 - vegetation }\end{array}$ & $\begin{array}{l}45.216504 \\
27.922864\end{array}$ \\
\hline 17 & $\begin{array}{l}\text { Slobozia roundabout (Kaufland), Bucuresti-Constanta } \\
\text { highroad, Amara highroad, Matei Basarab Bld. }\end{array}$ & $\begin{array}{l}\text { S17 - road dust } \\
\text { V17 - vegetation }\end{array}$ & $\begin{array}{l}44.562656, \\
27.349481\end{array}$ \\
\hline
\end{tabular}

Table 1

GEOGRAPHIC COORDINATES OF SAMPLING POINTS FOR SOIL AND VEGETATION 


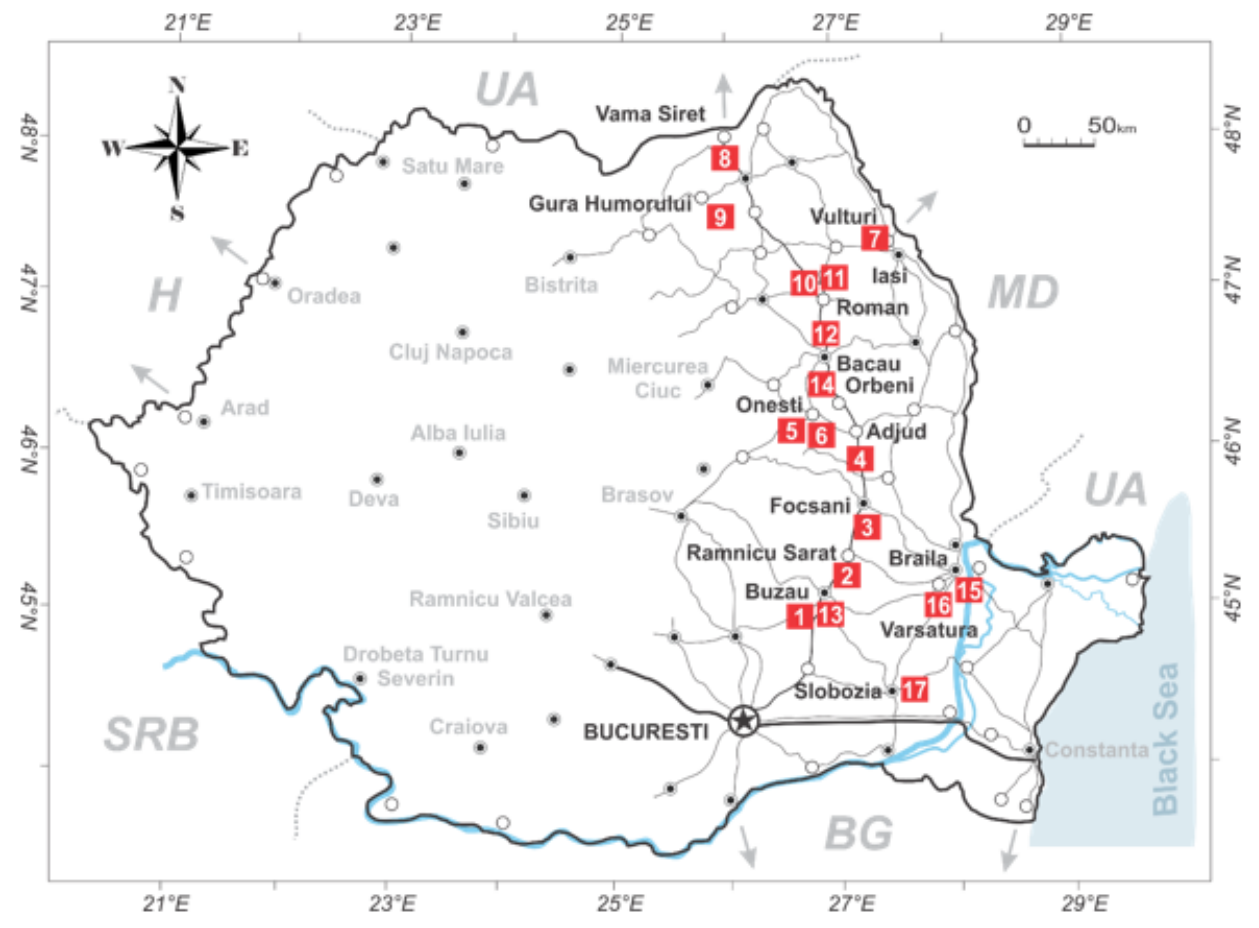

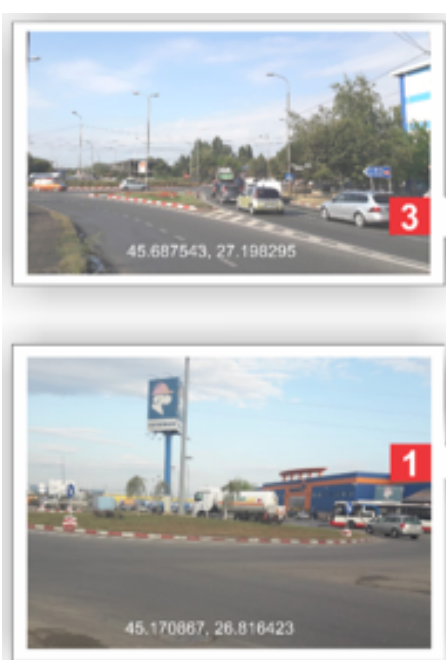

Adjud, while in Ramnicu Sarat the car traffic ranges from 8,001 to 16,000 vehicles / $24 \mathrm{~h}$.

In the area of Onesti (E574), the car traffic ranges from 3,501 to 8,000 vehicles / $24 \mathrm{~h}$ (fig. 3).

Sampling points 15, 16 in Braila County are located in areas with high car traffic, with the number of vehicles ranging from 8,001 to 16,000 vehicles / $24 \mathrm{~h}$ (fig. 4). Slobozia,

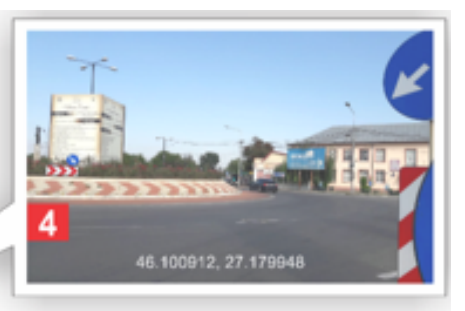

Fig. 2. Detail of sampling points E85, DN2

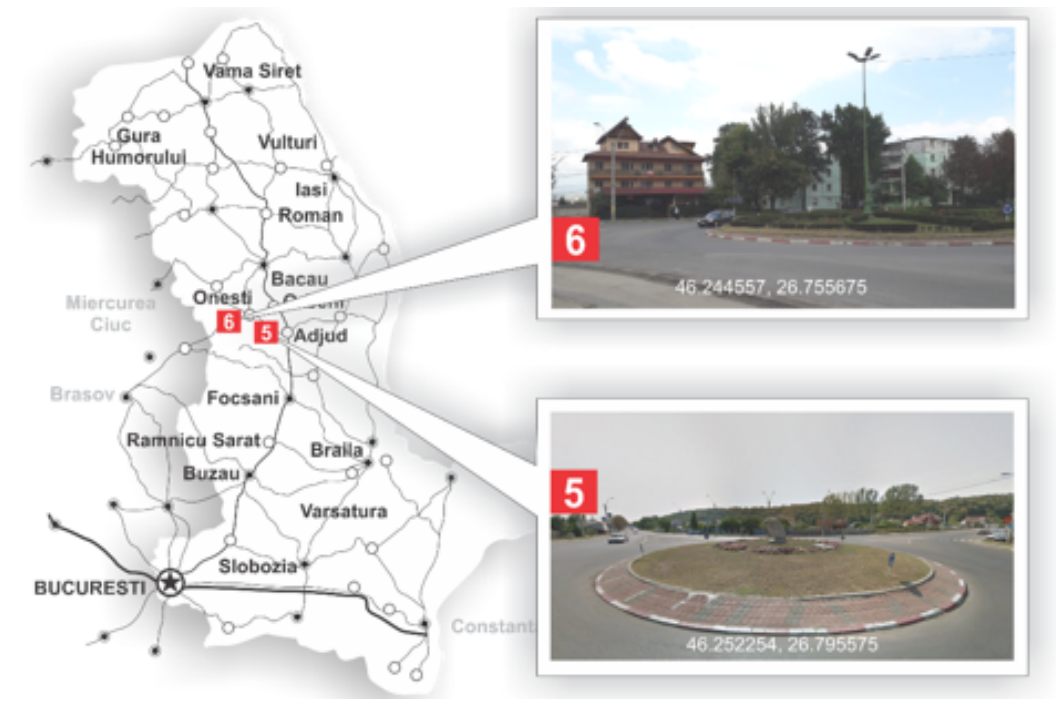

Fig. 3. Detail of sampling points Onesti 


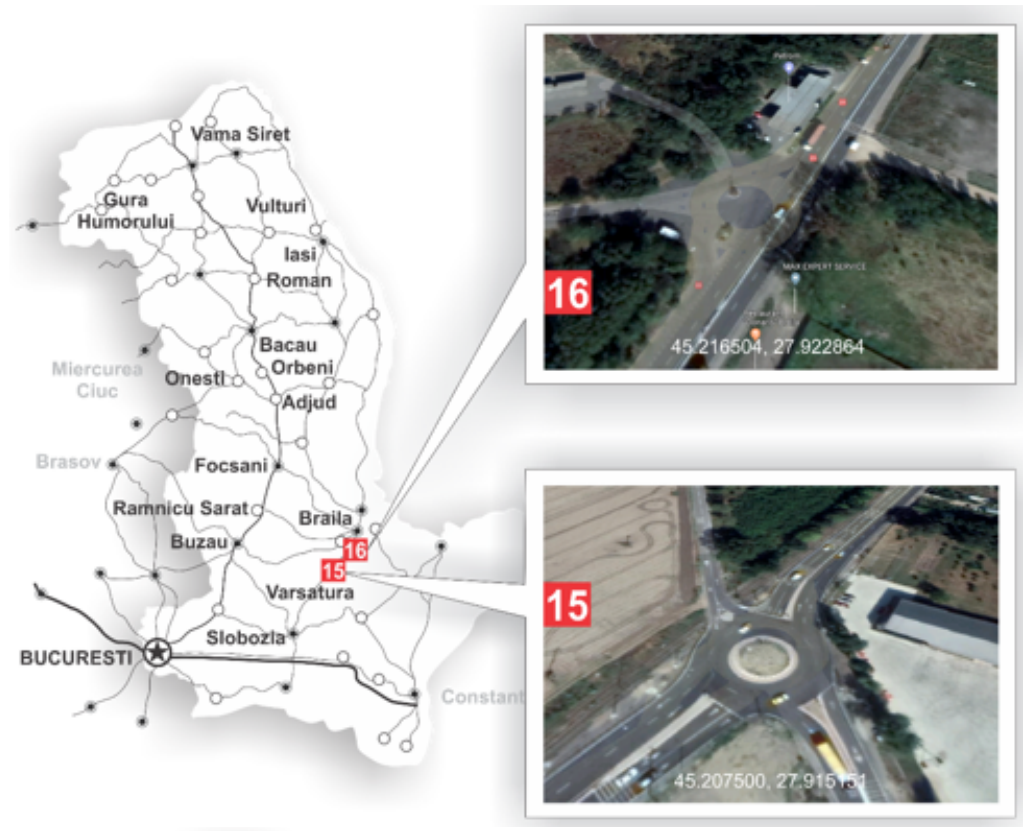

Fig. 4. Detail of sampling points, Braila county

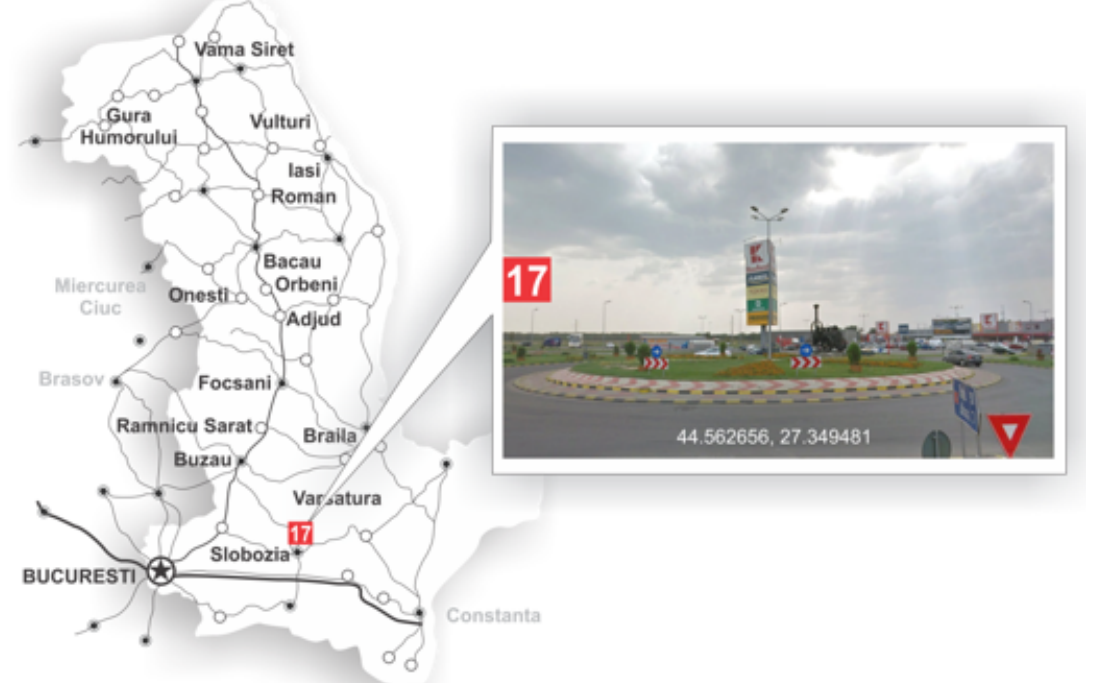

Fig. 5. Detail of sampling points Slobozia

-ICP-MS Aurora M90 Bruker

The performance parameters of the applied methods are presented in tables 2 and 3.

Table 2

PERFORMANCE PARAMETERS OF PGE USING USN-ICP-EOS TECHNIQUE

\begin{tabular}{|c|c|c|c|c|c|c|c|}
\hline $\begin{array}{l}\text { Metal } \\
\Lambda, \mathrm{nm}\end{array}$ & $\begin{array}{l}\text { LOD } \\
\mu \mathrm{g} / \mathrm{L}\end{array}$ & $\mathrm{LOQ} \mu \mathrm{g} / \mathrm{L}$ & $\begin{array}{c}\text { Acuracy } \\
\mu \mathrm{g} / \mathrm{L}\end{array}$ & $\underset{\%}{\text { RSDr* }}$ & $\operatorname{RSD}_{\mathrm{Ri}}{ }^{* *} \%$ & $\begin{array}{c}\text { Uex**** } \\
\%\end{array}$ & $\begin{array}{c}\text { Recovery } \\
\%\end{array}$ \\
\hline $\begin{array}{c}\operatorname{Ir} \\
224.268\end{array}$ & 1.36 & 4.50 & $\begin{array}{l}0.6 \div 6.8 / 30 \\
1.8 \div 4.2 / 50\end{array}$ & 2.89 & 4.91 & 7.21 & $83.3 \div 95.5$ \\
\hline $\begin{array}{c}\text { Pd } \\
248.892\end{array}$ & 1.20 & 4.00 & $\begin{array}{l}2.2 \div 3.9 / 30 \\
1.9 \div 5.9 / 50\end{array}$ & 2.56 & 3.35 & 13.3 & $81.2 \div 105$ \\
\hline $\begin{array}{c}\mathrm{Pt} \\
193.700\end{array}$ & 1.94 & 6.5 & $\begin{array}{c}3.7 \div 16 / 120 \\
14.5 \div 28 / 200\end{array}$ & 1.75 & 2.79 & 7.38 & $86.0 \div 96.9$ \\
\hline $\begin{array}{c}\mathrm{Rh} \\
343.489\end{array}$ & 0.60 & 2.00 & $\begin{array}{l}0.6 \div 0.9 / 30 \\
0.3 \div 3.6 / 50\end{array}$ & 3.48 & 5.84 & 7.44 & $98.8 \div 105$ \\
\hline $\begin{array}{c}\text { Ru } \\
349.894\end{array}$ & 0.72 & 2.40 & $\begin{array}{l}1.3 \div 6.4 / 30 \\
1.7 \div 12 / 50\end{array}$ & 2.26 & 3.26 & 11.2 & $75.7 \div 96.6$ \\
\hline
\end{tabular}

Table 3

PERFORMANCE PARAMETERS OF PGE USING ICP-MS TECHNIQUE

\begin{tabular}{|c|c|c|c|c|}
\hline Metal isotope & LOD $\mu$ g/L & LOQ $\mu$ g/L & RSDr* $\%^{*}$ & Uex ** \% \\
\hline Ir 193 & 0.60 & 2.00 & 5.40 & 10.9 \\
\hline Pd 105 & 0.07 & 0.25 & 1.15 & 6.85 \\
\hline Pt 195 & 1.05 & 3.50 & 10.7 & 15.9 \\
\hline Rh 103 & 0.05 & 0.17 & 0.55 & 5.60 \\
\hline Ru 102 & 0.09 & 0.29 & 1.24 & 7.54 \\
\hline
\end{tabular}

${ }^{*}$ Repeatability; ${ }^{* *}$ Measurement uncertainty 


\section{Results and discussions}

Determinations of platinum metals from the road dust and vegetation samples presented in tables 4 and 5 were made by ICP-MS. It is noted that both the iridium, ruthenium and platinum content in road dust and vegetation samples are below the limit of quantification of the applied method (50 $\mu \mathrm{g} / \mathrm{kg}$ to $\mathrm{Ir}, 10 \mu \mathrm{g} / \mathrm{kg}$ to Ru and $90 \mu \mathrm{g} / \mathrm{kg}$ to Pt ), while rhodium concentrations are small, below $20 \mu \mathrm{g} / \mathrm{kg}$ for both matrix types (tables 2 and 3). Palladium concentrations are situated in the range of hundreds of $\mu \mathrm{g} / \mathrm{kg}$ in soil and in the range of tens of hundreds of $\mu \mathrm{g} / \mathrm{kg}$ in vegetation. The highest Pd content was recorded in sections S1 - S4 (fig. 2), S5-S6 (fig. 3), the highest concentration being reported in S3 (Focsani, DN2, $794 \mu \mathrm{g} / \mathrm{kg} \mathrm{dm}=$ dry matter), (fig. 4).

As mentioned above, the Focsani area has a very intense car traffic (more than 16,000 vehicles / $24 \mathrm{~h}$ ), which is reflected also in the recorded PGEs concentrations.
PGEs values for soil samples are compared with both terrestrial crustreference values and other data for different European countries (table 6). Comparing the values obtained for the dust samples for Pd with the values obtained in other geographic areas, it can be observed that the maximum value is below that reported by Gomez et al., the average value being very close to that recorded in Madrid in 2001 [19]. Concerning the Rh content, the concentrations recorded in the studied sections are close to the values recorded in Moscow and reported in the study published by Ladonin in 2018 [12]. The maximum value obtained in the analysed samples $(0.014 \mathrm{mg} / \mathrm{kg} \mathrm{dm})$ is situated around the mean value $(0.0179 \mathrm{mg} / \mathrm{kg} \mathrm{dm})$ reported in Moscow. The statistical processing of the obtained results is presented in table 6 for road dust samples, respectively in table 7 for vegetation samples.

\begin{tabular}{|c|c|c|c|c|c|c|c|c|c|c|}
\hline & UM & S1 & S2 & S3 & S4 & S5 & S6 & S7 & S8 & 59 \\
\hline$\overline{\operatorname{Ir}(193)}$ & $\mu \mathrm{g} / \mathrm{kg} \mathrm{dm}$ & $<50$ & $<50$ & $<50$ & $<50$ & $<50$ & $<50$ & $\approx 50$ & $<50$ & $<50$ \\
\hline & $\mu \mathrm{g} / \mathrm{kg}$ & & 18 & 7 & 6. & & & & & \\
\hline & $\mu \mathrm{g} / \mathrm{k}$ & $\Leftrightarrow 9$ & $=90$ & $\approx 90$ & $=90$ & $=9$ & $=90$ & $\approx 90$ & $\approx 90$ & $<90$ \\
\hline & $\mu \mathrm{g} / \mathrm{k}$ & 13 & 13. & 11. & 9.3 & 8.8 & 8. & 7.1. & 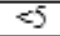 & 7.5 \\
\hline $\mathrm{Ru}(102)$ & $\mu \mathrm{g} / \mathrm{kg} \mathrm{dm}$ & $\approx 10$ & $\approx 10$ & $\approx 10$ & $<10$ & $\approx 10$ & $\approx 10$ & $<10$ & $<10$ & $\approx 10$ \\
\hline
\end{tabular}

Table 4

CONTENT OF PGE IN ROAD DUST SAMPLES

\begin{tabular}{|c|c|c|c|c|c|c|c|c|c|}
\hline Metal & $\overline{\mathrm{UM}}$ & S10 & S11 & S12 & S13 & S14 & S15 & S16 & S17 \\
\hline $\operatorname{Ir}(193)$ & $\mu \mathrm{g} / \mathrm{kg} \mathrm{dm}$ & $<50$ & $<50$ & $<50$ & $<50$ & $<50$ & $<50$ & $<50$ & $<50$ \\
\hline $\mathrm{Pd}(105)$ & $\mu \mathrm{g} / \mathrm{kg} \mathrm{dm}$ & 371 & 509 & 430 & 361 & 505 & 309 & 448 & 357 \\
\hline $\mathrm{Pt}(195)$ & $\mu \mathrm{g} / \mathrm{kg} \mathrm{dm}$ & $=90$ & $=90$ & $\approx 90$ & $=90$ & $<90$ & $<90$ & $<90$ & $\approx 90$ \\
\hline $\mathrm{Rh}(103)$ & $\mu \mathrm{g} / \mathrm{kg} \mathrm{dm}$ & 5.38 & 6.65 & 7.53 & 6.85 & 8.06 & $<5$ & $<5$ & 5.89 \\
\hline $\mathrm{Ru}(100)$ & $\mu \mathrm{g} / \mathrm{kg} \mathrm{dm}$ & $<10$ & $<10$ & $<10$ & $\approx 10$ & $<10$ & $<10$ & $<10$ & $\approx 10$ \\
\hline
\end{tabular}

\begin{tabular}{|c|c|c|c|c|c|c|c|c|c|c|}
\hline Metal & UM & V1 & V2 & V3 & V4 & V5 & V6 & V7 & V8 & V9 \\
\hline Ir & $\mu \mathrm{g} / \mathrm{kg} \mathrm{dm}$ & $<50$ & $<50$ & $<50$ & $<50$ & $<50$ & $<50$ & $<50$ & $<50$ & $<50$ \\
\hline $\mathrm{Pd}$ & $\mu \mathrm{g} / \mathrm{kg} \mathrm{dm}$ & 363 & 13 & 326 & 304 & 85 & $<6$ & 232 & 191 & 134 \\
\hline $\mathrm{Pt}$ & $\mu \mathrm{g} / \mathrm{kg} \mathrm{dm}$ & $<90$ & $<90$ & $<90$ & $<90$ & $<90$ & $<90$ & $<90$ & $<90$ & $=90$ \\
\hline $\mathrm{Rh}$ & $\mu \mathrm{g} / \mathrm{kg} \mathrm{dm}$ & 19.1 & $<5$ & 10.2 & 15.6 & $<5$ & $<5$ & 8.58 & $<5$ & 5.66 \\
\hline $\mathrm{Ru}$ & $\mu \mathrm{g} / \mathrm{kg} \mathrm{dm}$ & $<10$ & $<10$ & $<10$ & $<10$ & $<10$ & $<10$ & $<10$ & $<10$ & $<10$ \\
\hline
\end{tabular}

Table 5

CONTENT OF PGE IN VEGETATION SAMPLES

\begin{tabular}{|c|c|c|c|c|c|c|c|c|c|}
\hline Metal & $\overline{\mathrm{UM}}$ & V10 & $\overline{\text { V11 }}$ & V12 & $\overline{V 13}$ & $\overline{\text { V14 }}$ & V15 & V16 & V17 \\
\hline $\mathrm{Ir}$ & $\mu \mathrm{g} / \mathrm{kg} \mathrm{dm}$ & $<50$ & $<50$ & $<50$ & $<50$ & $<50$ & $<50$ & $<50$ & $\approx 50$ \\
\hline $\mathrm{Pd}$ & $\mu \mathrm{g} / \mathrm{kg} \mathrm{dm}$ & 93 & 128 & 20 & 283 & 125 & 172 & 131 & 17 \\
\hline $\mathrm{Pt}$ & $\mu \mathrm{g} / \mathrm{kg} \mathrm{dm}$ & $\approx 90$ & $=90$ & $=90$ & $=90$ & $=90$ & $=90$ & $\approx 90$ & $\Leftrightarrow 9$ \\
\hline $\mathrm{Rh}$ & $\mu \mathrm{g} / \mathrm{k}$ & 5 & 5.27 & 10.2 & 11.9 & 5.42 & 5.74 & 5.77 & \\
\hline $\mathrm{Ru}$ & $\mu \mathrm{g} / \mathrm{kg} \mathrm{dm}$ & $<10$ & $<10$ & $<10$ & $<10$ & $<10$ & $<10$ & $<10$ & $<10$ \\
\hline
\end{tabular}

\section{Table 6}

RESULTS OF PGE IN SOIL SAMPLES COMPARED TO LITERATURE DATA (mg/kg dm)

\begin{tabular}{|c|c|c|c|c|c|}
\hline Element & Ir & $\mathbf{P d}$ & $\mathrm{Pt}$ & $\mathbf{R h}$ & $\mathbf{R u}$ \\
\hline Average value & $=0.05$ & 0.496 & $<0.09$ & 0.008 & $<0.01$ \\
\hline Minimum value & $=0.05$ & 0.309 & $<0.09$ & $0.003(\approx 0.005)$ & $<0.01$ \\
\hline Maximum value & $=0.05$ & 0.794 & $<0.09$ & 0.014 & $<0.01$ \\
\hline Standard deviation & - & 0.127 & - & $0.002(\approx 0.005)$ & - \\
\hline \multicolumn{6}{|c|}{ Crust - reference values } \\
\hline Fersman [7] & 0.01 & 0.05 & 0.2 & 0.01 & 0.05 \\
\hline Vinogradov [8] & 0.001 & 0.01 & 0.005 & 0.001 & 0.005 \\
\hline Greenwood [9] & 0.001 & 0.015 & $\begin{array}{l}0.001- \\
0.005\end{array}$ & 0.0001 & 0.0001 \\
\hline Lide [10] & 0.001 & 0.015 & 0.005 & 0.001 & 0.001 \\
\hline \multicolumn{6}{|c|}{ Concentrations in dust - other areas studied } \\
\hline \multicolumn{6}{|c|}{ Moscova $[12]$} \\
\hline Average value & 0.0039 & 0.0708 & 0.158 & 0.0179 & 0.0016 \\
\hline Minimum value & 0.0016 & 0.0077 & 0.0124 & 0.0027 & 0.0007 \\
\hline Maximum value & 0.0062 & 0.2253 & 0.3566 & 0.0545 & 0.0022 \\
\hline UK [20] & - & 0.0093 & 0.070 & - & - \\
\hline Israel [21] & - & - & 1.230 & 0.381 & - \\
\hline Madrid [19] & - & $\begin{array}{c}0.317 \text { (mean) } \\
2.25 \text { (max) }\end{array}$ & - & $\begin{array}{c}0.074 \text { (mean) } \\
0.182 \text { (max) }\end{array}$ & - \\
\hline Viena [22] & - & $0.20-1.23$ & $0.21-1.45$ & - & - \\
\hline
\end{tabular}




\begin{tabular}{|l|c|c|c|c|c|}
\hline \multicolumn{1}{|c|}{ Element } & Ir & Pd & Pt & Rh & Ru \\
\hline Average value & $<0.05$ & 0.174 & $<0.09$ & 0.007 & $\approx 0.01$ \\
\hline Minimum value & $<0.05$ & $0.001(<0.006)$ & $<0.09$ & $0.001(<0.005)$ & $\approx 0.01$ \\
\hline Maximum value & $<0.05$ & 0.363 & $<0.09$ & 0.019 & $\approx 0.01$ \\
\hline Standard deviation & - & 0.048 & - & $0.002(<0.005)$ & - \\
\hline
\end{tabular}

Table 7

STATISTICAL RESULTS OF PGE FROM VEGETATION SAMPLES (mg/kg dm)

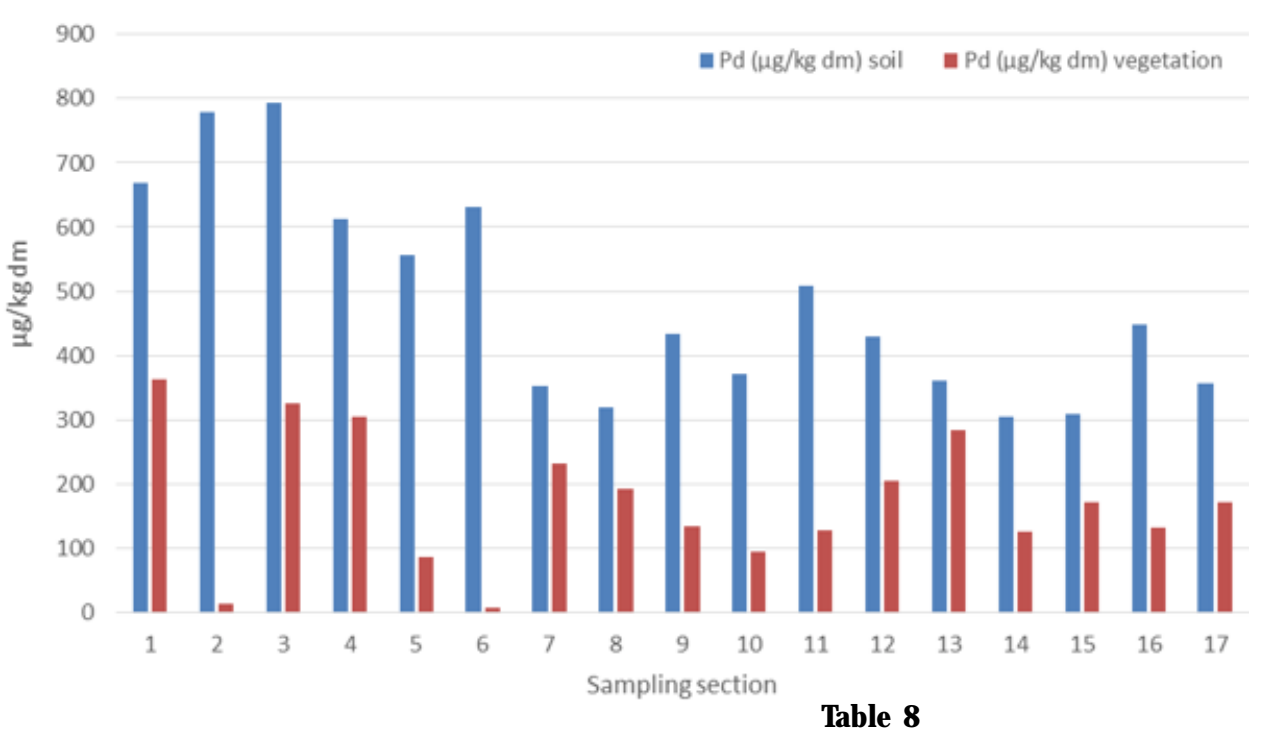

Fig. 6. Distribution of $\mathrm{Pd}$ content in samples of dust and vegetation collected from areas with intense traffic

Pd TRANSFER FACTOR FROM SOIL TO VEGETATION

\begin{tabular}{|c|c|c|c|c|c|c|c|c|c|}
\hline FT & $\mathbf{l}$ & $\mathbf{2}$ & $\mathbf{3}$ & $\mathbf{4}$ & $\mathbf{5}$ & $\mathbf{6}$ & $\mathbf{7}$ & $\mathbf{8}$ & $\mathbf{9}$ \\
\hline $\mathrm{Pd}$ & 0.54 & 0.02 & 0.41 & 0.50 & 0.15 & 0.01 & 0.66 & 0.60 & 0.31 \\
\hline FT & $\mathbf{1 0}$ & $\mathbf{1 1}$ & $\mathbf{1 2}$ & $\mathbf{1 3}$ & $\mathbf{1 4}$ & $\mathbf{1 5}$ & $\mathbf{1 6}$ & $\mathbf{1 7}$ & \\
\hline $\mathrm{Pd}$ & 0.25 & 0.25 & 0.48 & 0.78 & 0.41 & 0.56 & 0.29 & 0.48 & \\
\hline
\end{tabular}

Figure 6 shows graphically the $\mathrm{Pd}$ concentrations both in soil and vegetation samples, observing in some areas a high transfer factor. The transfer factor, representing the concentration of metal in vegetation relative to the metal concentration in the soil, ranges from 0.01 to 0.78 , with an average value of 0.39 , the highest value being recorded at point 13 (Roundabout Buzau, Industriilor Bld.). Another sample of vegetation harvested from another crossroad in Buzau, sample 1, also shows a high transfer factor (0.54).

Approximately $50 \%$ of the vegetation samples have a transfer factor higher than 0.5 , indicating the presence of bioavailable palladium compounds in the road dust that passes through the root to the aerial parts of the nearby vegetation.

Determinations performed using the USN-ICP-EOS technique both in soil and vegetation indicated concentrations below the determination limitfor $\mathrm{Pt}(<0.20$ $\mathrm{mg} / \mathrm{kg} \mathrm{dm}), \operatorname{Rh}(0.10 \mathrm{mg} / \mathrm{kg} \mathrm{dm})$ and $\mathrm{Ru}(0.12 \mathrm{mg} / \mathrm{kg}$ $\mathrm{dm})$, while the $\mathrm{Ir}$ and $\mathrm{Pd}$ concentrations are altered by interference from other metals ( $\mathrm{Fe}, \mathrm{Ni}, \mathrm{W}$ ) that cannot be removed by applying interference removal methods from the Syngistics software of the ICP-EOS Avio 500 Perkin Elmer equipment. The peaks of samples and samples overlap, but the interferences are recorded in tens and hundreds of wavelengths, so that these concentrations (in the order of tens-hundred $\mathrm{mg} / \mathrm{kg} \mathrm{dm}$ in the case of soils, respectively units of $\mathrm{mg} / \mathrm{kg} \mathrm{dm}$ in the case of vegetation) did not reflect real situation compared to similar data obtained by other researchers as well as concentrations determined by ICP-MS.

\section{Conclusions}

The content of $\mathrm{Ir}, \mathrm{Pd}, \mathrm{Pt}, \mathrm{Rh}$ and Ru was determined in 17 samples of road dust and vegetation, samples taken from several European and national roads located in the eastern part of Romania in areas with intense traffic. The concentrations of Ir, Pt, Ru were below the limit of determination of the applied method in both soil and vegetation samples. Approximately $50 \%$ of the vegetation samples have a transfer factor more than 0.5 for $\mathrm{Pd}$, indicating a translocation of bioavailable Pd compounds from the soil through the root to the aerial vegetation part. The reported values for $\mathrm{Pd}$ and $\mathrm{Rh}$ in road dust are in the range of concentrations similar to other polluted traffic areas in Europe.

Acknowledgements. The authors acknowledge the financial support offered by The National Research Program Nucleu through Agreement no. 38N/2018, Project code PN 18050101.

\section{References}

1.PAWLAK J, CHRUSCINSKA E.L., CHRUSTOWICZ J., J. Trace Elem. Med. Bio., 28, 2014, p. 247.

2.SOARE V., DUMITRESCU D., BURADA M., CONSTANTIN I., SOARE V., CAPOTA P., POPESCU A.M., CONSTANTIN V, Rev. Chim. (Bucharest), 67, no.5, 2016, p. 920.

3.MIHAI S., NEGOIU M., Rev. Chim. (Bucharest), 63, no. 7, 2012, p. 697.

4.RAVINDRA K., BENCS L., VAN GRIEKEN R., Sci. Total Environ., 318, 2004, p. 1.

5.BUCUR E., DANET A., Rev. Chim. (Bucharest), 67, no. 4, 2016, p. 621.

6.PETRESCU M., BUCUR E., DIODIU R., BRATU M., SERBANESCU A., BARBU M., $20^{\text {th }}$ International Symposium The Environment and the Industry, Proceedings Book, 2017, p.213.

7.FERSMAN A.E., Geochemistry, Academy of Science of Soviet Union Publishing House, Moscow, vol. 1-4, 1955-1959.

8.VINOGRADOV A.P., Geokhimiya, 1, 1962, p. 6.

9.GREENWOOD N.N., EARNSHAW A., Chemistry of the Environment, Pergamon, Oxford, 1989, p. 1242.

10.LIDE D.R. (ed.), CRC Handbook of Chemistry and Physics, Section 14: Geophysics, Astromony and Acoustics (Abundence of Elements in the Earth's Crust and in the Sea), 2005, p. 2373, Internet Version 2005, <http://www.hbcpnetbase.com>, CRC Press, Boca Raton, FL. 11.BARANOWSKA K.M., MATYJA I, Electroanalysis, 19, 2007, p. 1585. 12.LADONIN, D.V, Eurasian Soil Sci., 51, no. 3, 2018, p. 268.

13.0J EDA C.B., ROJAS F.S., Talanta, 71, 2007, p. 1. 
14.FORNIELES A.C., GARCIA DE TORRES A., ALONSO E.V., PAVON J.M.C., Microchem. J., 124, 2016, p. 82.

15.ZAMBRZYCKA-SZELEWA E., LULEWICZ M., GODLEWSKAZYLKIEWICZ B., Spectrochim. Acta Part B, 133, 2017, p. 81.

16.TENEA, A., DINU, C., UNGUREANU, E.M., VASILE, G.G., SIMION, M., $21^{\text {th }}$ International Symposium The Environment and the Industry, Proceedings Book, 2018, p.366.

17.TSOGASG.Z., GIOKASD.L., VLESSIDIS A.G., EVMIRIDIS N.P., Talanta, 76, 2008, p. 635.

18.*** National Company for Road Infrastructure Administration (CESTRIN), http://www.cestrin.ro/web2014/trafic.html
19.GOMEZ B., GOMEZ M., SANCHEZ J ., FERNANDEZ R., PALACOIS M.A., Sci. Total Environ., 269, no. 1-3, 2001, p. 131.

20.FARAGO M.E., HUTCHINSON E.J., CHANDRAN N., SIMPSON P.R., Increases in platinum metals in the UK and possible health effects, in Metal Ions in Biology and Medicine, John Libbey Eurotext, 2000, Paris, vol. 6.

21.TEUTSCH N., HARLAVAN Y., HALICZ L., Level and distribution of Platinum Group Metals (PGM) in Israel, Ministry of National infrastructures, Geological Survey of Israel, report GSI/23/2013. 22.WISEMAN C.L.S., NIU J ., LEVESQUE C., CHENIER M., Environ. Pollut., 241, 2018, p. 1009.

$\overline{\text { Manuscript received: } 12.08 .2018}$ 